\title{
Determining Intervention for Behaviour-Based Safety (BBS) Implementation in Building Construction Project
}

\author{
1,2 Yohanes Eka Prayuda \\ ${ }^{1}$ United Tractors, Cakung \\ ${ }^{2}$ Master of Mechanical Engineering \\ Swiss German University \\ Tangerang City, Indonesia \\ eka.prayuda@gmail.com \\ Gembong Baskoro \\ Master of Mechanical Engineering \\ Swiss German University \\ Tangerang City, Indonesia \\ gembong.baskoro@sgu.ac.id
}

\author{
Sumarsono Sudarto \\ Industrial Engineering Department \\ Mercubuana University \\ Jakarta, Indonesia 11650 \\ sumarsono@mercubuana.ac.id
}

\author{
Edi Sofyan \\ Master of Mechanical Engineering \\ Swiss German University \\ Tangerang City, Indonesia \\ edi.sofyan@lecturer.sgu.ac.id \\ Aditya Tirta Pratama \\ Master of Mechanical Engineering \\ Swiss German University \\ Tangerang City, Indonesia \\ aditya.pratama@sgu.ac.id
}

Abstract - The construction works value in country has been increased for the last 5 years, so does the workplace accident number that boosts consideration of safety issue in industry, including the listed private construction firm. Its revenue growth in the last 3 years, was offset by decreased total number of workplace accidents in contrary to the increased workplace's major accidents number. About $75 \%$ of company's workplace accident involved subcontractors, over $60 \%$ of its root causes were dealing with Unsafe Behavior, and 68\% of workplace accidents in 2019 caused by Unsafe Action. It triggers a strong impetus to initiate Behavior Based Safety implementation, by the DO-IT (Define-Observe-Intervene-Test) approach using indepth interview, structured self-assessment questionnaires and statistical tests. The findings deal with Safety Key Behavior (SKB) criteria in 17 areas of entire construction works through formulating at-risk behavior that leads to unsafe action by the workers, grouped into 3 circles of processes, i.e., execution, supervision and planning/ management. This study contributes to address mutual obligation between company and subcontractors in prioritizing safety behavior improvement to help the policy makers enhancing safety performance in the industry.

Keywords-behavior based safety, safety key behavior, unsafe action, at-risk behavior, statistics. 